\title{
80 歳以上の高齢者胃癌に招ける外科治療上の問題点
}

\begin{tabular}{lrrrrrr} 
& \multicolumn{7}{c}{ 新潟県立がんセンター新潟病院外科 } & & \\
東山 & 考一 & 梨本 & 篤 & 佐々 木壽英 & 赤井 & 貞彦 \\
加藤 & 清 & 佐野 & 宗明 & 筒井 光広 & &
\end{tabular}

\begin{abstract}
80 歳以上を高齢者とし, 高齢者胃癌症例 66 例と 74 歳以下の胃癌症例 4,066 例との間で種々の臨床病理 学的事項について比較検討し，高齢者胃癌の持つ外科治療上の問題点を追求した. その結果：1）両者 間の切除率および胃全摘率に差はなかったが，切除直死率は74歳以下群の $0.8 \%$ と比べて $5.3 \%$ と高齢 者群で有意に高く $(\mathrm{p}<0.05), 22.8 \%$ の術後合併症の発生をみた．2）組織学的に分化型が多く, リン 巫節転移陽性率は高い傾向にあった.3）両者の治瘦切除例に招ける 5 年生存率は他病死を除くと74歳 以下群 $74.8 \%$ ，高㱓者群 $66.2 \%$ であるが，他病死を含むとそれぞれ $72.1 \% ， 51.9 \%$ となり高㱓者群で 他病死が多く2られた，4）術後合併症の発生に関する危険因子として術前の肺活量（\%vc）が参考に なると考えられた，以上より quality of life を考虑し高齢者胃癌では全身状態に問題がなければ治癒 切除を目ざし，不良なるのは無理をしない合理的な手術が望ましいと考えられた。
\end{abstract}

Key words: gastric cancer in the aged (over 80years old), operative death of gastric cancer in the aged, post operative complications of gastric cancer in the aged, 5-year survival rate of gastric cancer in the aged

はじめに

胃癌多発国の日本において，急速な高龄化社会の到 来に伴い, 高龄者胃癌症例を治療する機会が増兄つつ あり, 術前・術中・術後の管理の進歩も合まって, 高 柃者胃癌の手術適応子拡大されている. 高齢者の概念 る時代とともに変化し，何歳以上を高秢者とするかは 論議のあるところである. 従来は70歳以上を高跉者胃 癌症例として論じた報告が多くみられたが，WHOの 定義（1963年）では75歳以上を老年者（aged）として おり, 今日実際の診療上70歳台の胃癌症例は決してま れではない. 当科における胃癌手術症例数の年龄別推 移をみても，1973年の寿医療開始後75歳以上の手術症 例が増加し, 最近 5 年間は 80 歳以上の胃癌症例の増加 も見受けられる(Fig. 1). 現在では70７5歳の患者の 治療に際して年龄のみを理由に治療方針を変更するこ とはまずないと考えられる。従って, 胃癌症例の外科 治療における高跲者の定義としては75歳以上が妥当と 考穴られ, 高㱓者胃癌のもつ外科治療上の問題点をよ り明確にする目的で 80 歳以上を高齢者胃癌とし，これ を74歳以下の胃癌症例と比較した。

$<$ 1990年11月19日受理 >別刷請求先: 東山 考一 T951 新潟市川岸町 2-10 新潟県立がんセンター 外科

\section{対象と方法}

1966年 1 月から 1988 年 12 月までの 23 年間に当科で経 験した全胃癌手術症例数は 4,341 例である。このうち, 80 藏以上 (最高路89歳) の高齢者胃癌症例 66 例（男 50 名, 女16名）之74歳以下の胃癌症例4,066例を対象に 種々の臨床病理学的事項について比較検討した。 また, 高齢者胃癌の種々の術前検査データと術後合併症との 関係を検索し, 術後合併症の発生に関する危険因子の 把握を試みた。

なお, 記載用語は胃癌取扱い規約1)に従い, 統計学的 な検定は $\chi^{2}$ 検定および $\mathrm{t}$ 検定によった。

\section{1）背景因子 \\ 1. 性別}

80 歳以上の高跉者群では, 男性 $75.8 \%$, 女性 $24.2 \%$ であり，74歳以下群の男性 $62.4 \%$, 女性 $37.6 \%$ に比べ て男性の占める割合が有意に高くなっており，高齢に なる汪ど男性に多い胃癌の特徵がより明らかになった $(\mathrm{p}<0.05)$.

\section{2. 占居部位}

癌の占居部位を, 手術所見和よび切除標本により分 類したところ, 80 歳以上の高齢者群では A 領域が $56.1 \%$ と過半数を占め, 74 歳以下群では $\mathrm{M}$ 領域を占め 
Fig. 1 Chronological trend of number of patients with gastric cancer

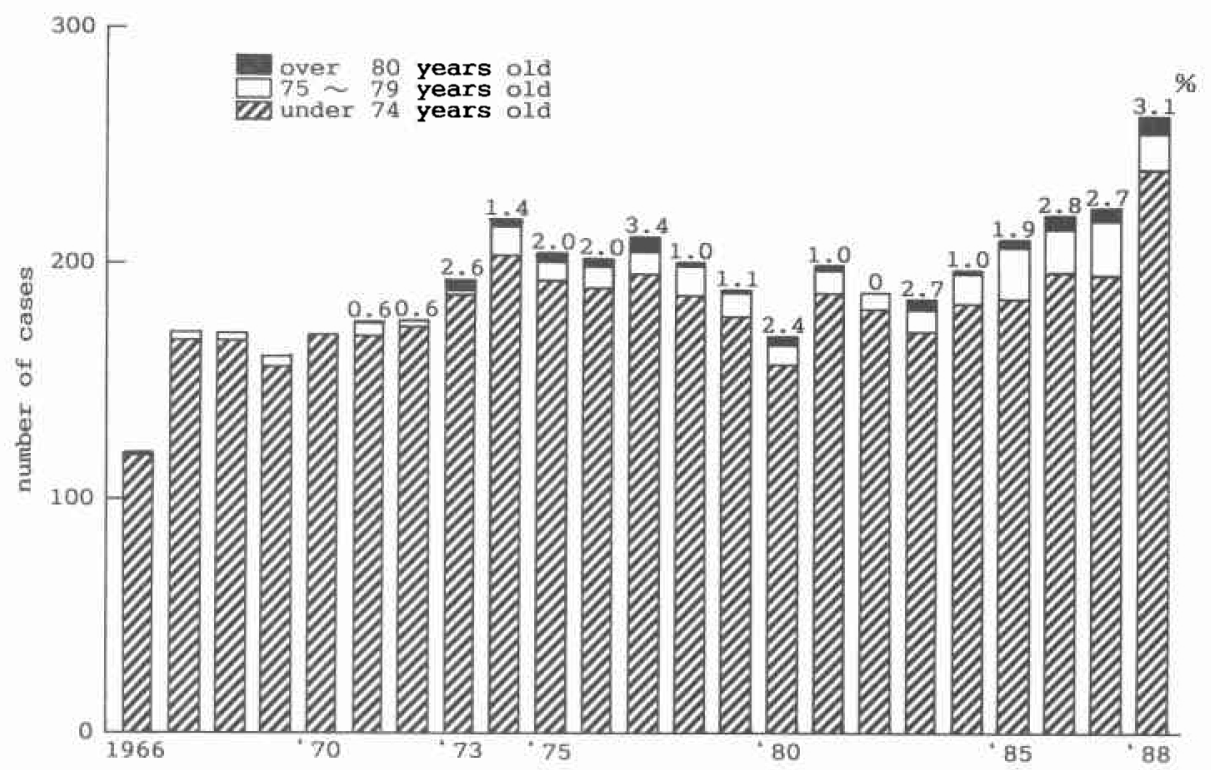

るものが比較的多くみられた（ $\mathrm{p}<0.05 ）$.

\section{3. 肉眼分類}

早期癌については，高齢者群ではI 型またはIIa 型 の隆起型の占める割合が有意に高かったが（ $\mathrm{p}<$ 0.05), 進行癌では特徵的な差異は認めなかった。

4. 進行度

stage 別に80歳以上の高齢者群と74歳以下群を比較 すると, 各 stage の頻度および切除率に差はみられず, 80歳以上の高齢者群といえども積極的に切除がなされ ていた.なお，開胸症例は経験していない.また75〜79 歳の胃癌症例でも各 stage の頻度と切除率に両群との 差は認めなかった。

深達度，P因子， $\mathrm{H}$ 因子別の頻度について両者間で 比較したところ，注同様の分布を示し差はみられな かった. 組織学的リンパ節転移陽性率は80歳以上で $61.4 \% ， 74$ 歳以下で $50.3 \%$ と有意差はなかったが， 80 歳以上の高齢者群ではリンパ節転移陽性率が高くなる 傾向にあり，とくに $\mathrm{n}_{2}(+)$ 症例が $33.3 \%$ と有意に高 率であった $(\mathrm{p}<0.05) .75$ 79歳の胃癌症例では深達 度， $\mathrm{P}$ 因子， $\mathrm{H}$ 因子は両者と注同様の分布であった が, 組織学的リンパ節転移陽性率は50.5\%で74歳以下 群と同様の傾向を示していた。

\section{5. 組織型}

切除例を対象に組織型をみると, 高齢者群では pap, $\mathrm{tub}_{1}, \mathrm{tub}_{2}$ といった分化型が71.2\%と高率を占め, por, sig, mucの低分化型は28.8\%と低率であった（p< 0.05) (Table 1).

2) 手術内容

80歳以上高龄者群の術式内訳をみると, 切除率は $86.4 \%$ (57例/66例) で，胃全摘率は28.1\%（16例/57 例）であった．非切除は $13.6 \%$ (9例/57例) であり， その主因子として $\mathrm{P}_{3}$ または $\mathrm{P}_{2}$ によるものが 5 例, $\mathrm{S}_{3}$ または $\mathrm{N}_{4}(+)$ によるあのが4例であった（Table 2). これを74歳以下群と比較すると,74歳以下群の切除率, 胃全摘率はおのおの $83.2 \% ， 26.5 \%$ だあ両者間に差 はみられなかった。切除直死率は74歳以下群の $0.8 \%$ に 対し，80歳以上群では $5.3 \%$ と有意に高率であった $(\mathrm{p}<0.05)$. しかし, 80歳以上の胃全摘例では直死例は 1 例も認めなかった(Table 3)。ぬた75～79歳群では， 切除率, 胃全摘率, 切除直死率および胃全摘直死率は それぞれ87.1\%(182例/209例)，20.9\%(38例/182例)， $1.1 \%$ (2例 $/ 182$ 例)， $0 \%$ (0/38例) であった。

次に, 年龄別のリンパ節郭清度をみると, 74歳以下 群は $\mathrm{R}_{2}$ 以上が $82.5 \%\left(\mathrm{R}_{2} 72.9 \%, \mathrm{R}_{3} 9.6 \%\right)$ を占め ているのに対し，80歳以上群では $\mathrm{R}_{0}$ たは $\mathrm{R}_{1}$ が $54.4 \%\left(\mathrm{R}_{0} 21.1 \%, \mathrm{R}_{1} 33.3 \%\right.$ ） と高くなる傾向がみ られた (Table 4).この結果, 年龄別の治癒切除度で は, 74歳以下群の77.8\%が治癒切除を受けているのに 対し，80歳以上の高齢者群では64.9\%にとどまり，有 意に低率であった（p<0.05）（Table 5).ちなみに 
Table 1 Comparison of charactaristics of patients with gastric cancer over 80 years of age and under 74 years of age

\begin{tabular}{|c|c|c|c|c|c|c|c|}
\hline & & roup & under 74 y & $s$ old & over 80 & old & \\
\hline & tem & & No. & $\%$ & No. & $\%$ & significance \\
\hline Sex & & $\begin{array}{l}\text { male } \\
\text { female }\end{array}$ & $\begin{array}{l}2573 / 4066 \\
1528 / 4066\end{array}$ & $\begin{array}{l}62.4 \\
37.6\end{array}$ & $\begin{array}{l}50 / 66 \\
16 / 66\end{array}$ & $\begin{array}{l}75.8 \\
24.2\end{array}$ & $P<0.05$ \\
\hline Location & & $\begin{array}{c}\mathrm{A} \\
\mathrm{M} \\
\mathrm{C} \\
\mathrm{AMC}\end{array}$ & $\begin{array}{r}1793 / 4102 \\
1150 / 4102 \\
678 / 4102 \\
481 / 4102\end{array}$ & $\begin{array}{l}43.7 \\
28.0 \\
16.5 \\
11.7\end{array}$ & $\begin{array}{r}37 / 66 \\
10 / 66 \\
10 / 66 \\
9 / 66\end{array}$ & $\begin{array}{l}56.1 \\
15.2 \\
15.2 \\
13.6\end{array}$ & $\begin{aligned} \text { N.S. } \\
\text { P<0.05 } \\
\text { N.S. } \\
\text { N.S. }\end{aligned}$ \\
\hline & $\begin{array}{l}\text { early } \\
\text { gastric } \\
\text { cancer }\end{array}$ & $\begin{array}{l}\mathrm{b} \cdot \text { II a } \\
\mathrm{c} \cdot \text { III }\end{array}$ & $\begin{array}{l}367 / 1101 \\
15 / 1101 \\
719 / 1101\end{array}$ & $\begin{array}{l}33.3 \\
1.4 \\
65.3\end{array}$ & $\begin{array}{l}9 / 16 \\
0 / 16 \\
7 / 16\end{array}$ & $\begin{array}{l}56.3 \\
43.7\end{array}$ & $\begin{array}{r}P<0.05 \\
\text { N.S. } \\
\text { N.S. }\end{array}$ \\
\hline Gross & $\begin{array}{l}\text { advanced } \\
\text { gastric } \\
\text { cancer }\end{array}$ & $\begin{array}{r}\text { rmann } \\
1 \\
2 \\
3 \\
4 \\
5\end{array}$ & $\begin{array}{r}91 / 2642 \\
1063 / 2642 \\
780 / 2642 \\
412 / 2642 \\
296 / 2642\end{array}$ & $\begin{array}{r}3.4 \\
40.2 \\
29.5 \\
15.6 \\
11.2\end{array}$ & $\begin{array}{r}4 / 47 \\
20 / 47 \\
11 / 47 \\
6 / 47 \\
6 / 47\end{array}$ & $\begin{array}{r}8.5 \\
42.6 \\
23.4 \\
12.8 \\
12.8\end{array}$ & $\begin{array}{l}\text { N.S. } \\
\text { N.S. } \\
\text { N.S. } \\
\text { N.S. } \\
\text { N.S. }\end{array}$ \\
\hline Depth of & invasion & $\begin{array}{l}\text { m } \\
\text { sm } \\
\text { pm } \\
\text { ss } \\
\text { se.sei }\end{array}$ & $\begin{array}{r}584 / 3383 \\
442 / 3383 \\
416 / 3383 \\
319 / 3383 \\
1622 / 3383\end{array}$ & $\begin{array}{r}17.3 \\
13.1 \\
12.3 \\
9.4 \\
47.9\end{array}$ & $\begin{array}{r}8 / 57 \\
8 / 57 \\
11 / 57 \\
4 / 57 \\
26 / 57\end{array}$ & $\begin{array}{r}14.0 \\
14.0 \\
19.3 \\
7.0 \\
45.6\end{array}$ & $\begin{array}{l}\text { N.S. } \\
\text { N.S. } \\
\text { N.S. } \\
\text { N.S. } \\
\text { N.S. }\end{array}$ \\
\hline $\begin{array}{r}\text { Peritone } \\
\text { di }\end{array}$ & Semination & $\mathbf{P}_{0}$ & $\begin{array}{r}3053 / 3384 \\
331 / 3384\end{array}$ & $\begin{array}{r}90.2 \\
9.8\end{array}$ & $\begin{array}{r}51 / 57 \\
6 / 57\end{array}$ & $\begin{array}{l}89.5 \\
10.5\end{array}$ & $\begin{array}{l}\text { N.S. } \\
\text { N.S. }\end{array}$ \\
\hline $\begin{array}{c}\text { Liver } \\
\text { meta }\end{array}$ & tasis & $\begin{array}{l}\mathrm{H}_{\mathbf{0}} \\
\mathrm{H}_{(+)}\end{array}$ & $\begin{array}{r}3253 / 3383 \\
130 / 3383 \\
\end{array}$ & $\begin{array}{r}96.2 \\
3.8\end{array}$ & $\begin{array}{r}53 / 57 \\
4 / 57 \\
\end{array}$ & $\begin{array}{r}93.0 \\
7.0\end{array}$ & $\begin{array}{l}\text { N.S. } \\
\text { N.S. }\end{array}$ \\
\hline Resectab & stage & II & $\begin{array}{c}1256 / 1256 \\
273 / 273 \\
1067 / 1075 \\
788 / 1462\end{array}$ & $\begin{array}{r}100 \\
100 \\
99.3 \\
53.9\end{array}$ & $\begin{array}{l}20 / 20 \\
5 / 5 \\
19 / 19 \\
13 / 22\end{array}$ & $\begin{array}{r}100 \\
100 \\
100 \\
59.1\end{array}$ & $\begin{array}{l}\text { N.S. } \\
\text { N.S: } \\
\text { N.S: } \\
\text { N.S. }\end{array}$ \\
\hline $\begin{array}{l}\text { Lỳmphnod } \\
\text { meta }\end{array}$ & sis & $\begin{array}{ll}n_{1} & (-) \\
n_{1} & (+) \\
n_{2} & (+) \\
n_{3} & (+) \\
n_{4} & (+)\end{array}$ & $\begin{array}{r}1683 / 3384 \\
717 / 3384 \\
717 / 3384 \\
159 / 3384 \\
108 / 3384\end{array}$ & $\begin{array}{r}49.7 \\
21.2 \\
21.2 \\
4.7 \\
3.2\end{array}$ & $\begin{array}{r}22 / 57 \\
13 / 57 \\
19 / 57 \\
1 / 57 \\
2 / 57\end{array}$ & $\begin{array}{r}38.6 \\
22.8 \\
33.3 \\
1.8 \\
3.5\end{array}$ & $\begin{array}{r}\text { N.S. } \\
\text { N.S. } \\
\text { P<O.05 } \\
\text { N.S. } \\
\text { N.S. }\end{array}$ \\
\hline $\begin{array}{r}\text { Histolog } \\
\text { type }\end{array}$ & al & $\begin{array}{l}\text { pap } \\
\text { tub } \\
\text { tub } \\
\text { por } \\
\text { muc } \\
\text { sig } \\
\text { others }\end{array}$ & $\begin{array}{r}259 / 3337 \\
856 / 3337 \\
860 / 3337 \\
1074 / 3337 \\
69 / 3337 \\
192 / 3337 \\
27 / 3337\end{array}$ & $\begin{array}{r}7.8 \\
25.6 \\
25.8 \\
32.2 \\
2.1 \\
5.8 \\
0.8\end{array}$ & $\begin{array}{r}4 / 66 \\
23 / 66 \\
20 / 66 \\
14 / 66 \\
2 / 66 \\
0 / 66 \\
3 / 66\end{array}$ & $\begin{array}{r}6.1 \\
34.8 \\
30.3 \\
21.2 \\
3.0 \\
0 \\
4.5\end{array}$ & $\begin{array}{l}P<0.05 \\
P<0.05\end{array}$ \\
\hline
\end{tabular}

Table 2 Operation method of gastric cancer patients over 80 years of age

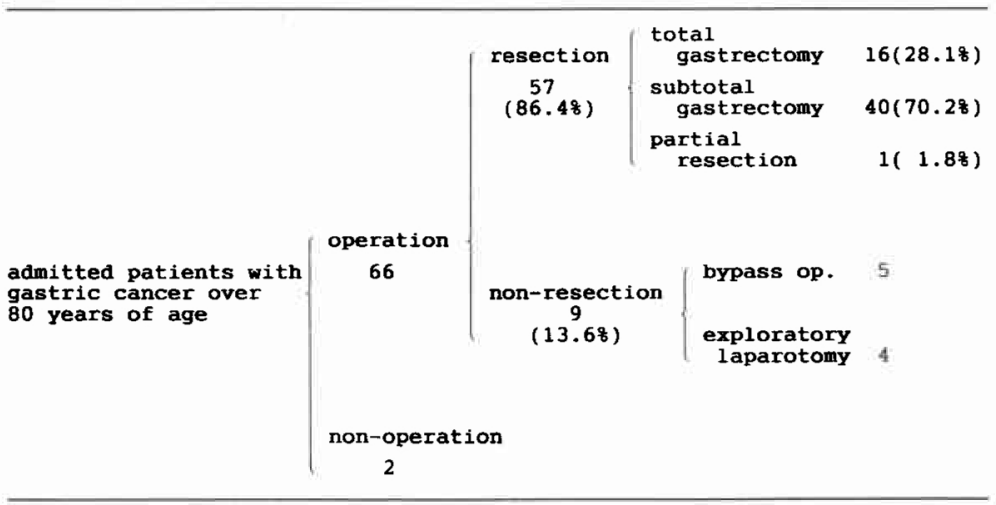

75〜79歳群 では, $\mathrm{R}_{2}$ 以上が70.3\% $\left(\mathrm{R}_{2} 62.1 \%, \mathrm{R}_{3}\right.$ $8.2 \%)$ で, 治瘦切除率が74.2\%となって扔り両群の中 間値をとっていた。

3) 予後

治癒切除例の累積生存率を Kaplan-Meier 法で求め たところ，74歳以下群では，他病死を含めた 5 年生存
率は72.1\%で，他病死を除くと74.8\%であった。一方， 高㱓者群に执いては, 他病死を含めた 5 年生存率は $51.9 \%$ である゙，他病死を除くと $66.2 \%$ となり，生存 率へ及济す他病死の影響が大きくみられ，特徴的な結 果であった。なお75～79歳群での 5 年生存率は, 他病 死を含めると $61.0 \%$ で,他病死を除くと $65.9 \%$ であり， 
Table 3 Comparison of operative methods between patients with gastric cancer over 80 years of age and under 74 years of age

\begin{tabular}{|c|c|c|}
\hline operation group & under 74 years old & over 80 years old \\
\hline number of oprated cases & 4066 & 66 \\
\hline $\begin{array}{l}\text { number of resected cases } \\
\text { resectability } \\
\text { *operative mortality rate }\end{array}$ & $\begin{array}{l}3384 \\
83.2 \% \\
{ }^{*} 0.88(27)\end{array}$ & $\begin{array}{l}57 \\
86.48 \\
\star_{5.38(3)}\end{array}$ \\
\hline $\begin{array}{l}\text { number of total gastrectomy } \\
\text { incidence of total gastrectomy } \\
\text { operative mortality rate } \\
\text { of total gastrectomy }\end{array}$ & $\begin{array}{l}897 \\
26.58 \\
1.18(10)\end{array}$ & $\begin{array}{c}16 \\
28.18 \\
08\end{array}$ \\
\hline
\end{tabular}

Table 4 Comparison of resectability grade of lymphnodal dissection between patients with gastric cancer over 80 years of age and under 74 years of age

\begin{tabular}{|c|c|c|c|c|}
\hline F-number group & under 74 & years old & over 80 & years old \\
\hline$R_{0}$ & $\left(\begin{array}{l}227 \\
8.28) \\
317 \\
(9.48)\end{array}\right\}$ & $17.5 \%$ & $\left.\begin{array}{c}12 \\
(21.18) \\
19 \\
(33.38)\end{array}\right\}$ & $54.4 \%$ \\
\hline $\begin{array}{l}\mathbf{R}_{\mathbf{2}} \\
\mathbf{R}_{\mathbf{3}}\end{array}$ & $\left.\begin{array}{c}2466 \\
(72.98) \\
324 \\
(9.68)\end{array}\right\}$ & $82.5 \%$ & $\left.\begin{array}{c}25 \\
(43.98) \\
1 \\
1.88)\end{array}\right)$ & $45.6 \%$ \\
\hline total & 3384 & cases & 57 & cases \\
\hline
\end{tabular}

Table 5 Comparison of curability rate between patients with gastric cancer over 80 years of age and under 74 years of age

\begin{tabular}{|c|c|c|c|c|}
\hline curability & under 74 & years old & over 80 & yeas old \\
\hline $\begin{array}{l}\text { Curative } \\
\text { resection }\end{array}$ & $\left.\begin{array}{c}2120 \\
(62.68) \\
514 \\
(15.28)\end{array}\right\}$ & ${ }^{*} 77.8 \%$ & $\left.\begin{array}{c}29 \\
(50.98) \\
8 \\
(14.08)\end{array}\right\}$ & ${ }^{*} 64.9 \%$ \\
\hline$\underbrace{A^{\# 3}}_{\text {non-curative }}$ & $\left.\begin{array}{c}230 \\
6.88) \\
520 \\
(15.48)\end{array}\right\}$ & $22.2 \%$ & $\left.\begin{array}{c}8 \\
(14.08) \\
12 \\
(21.18)\end{array}\right\}$ & $35.1 \%$ \\
\hline total & 3384 & cases & 57 & cases \\
\hline
\end{tabular}

\#1 absolute curative resection

(* $P<0.05)$

\#2 relative curative resection

\#3 relative non-curative resection

他病死の生存率への影響は80歳以上群に比べて少な かった (Fig. 2).

\section{4）術前併存疾患}

80歳以上の高齢者群において術前の併存疾患をみる と, 全体の有病率は65.2\%(43例/66例)にのぼり, 循
Fig. 2 Survival curves of curative resection in patientn with gastric cancer
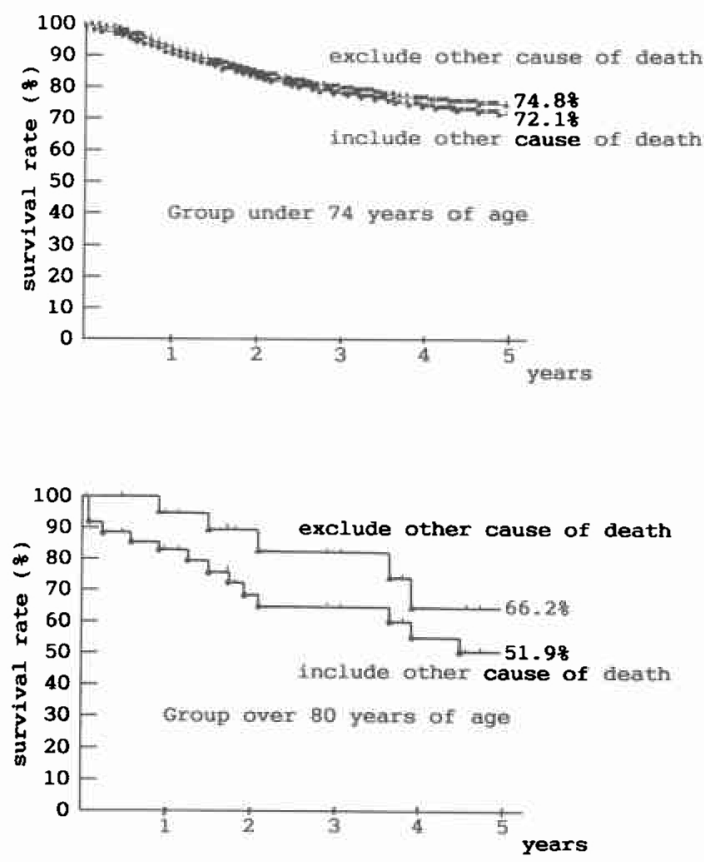

環器系, 呼吸器系がそれぞれ $24.2 \%, 15.2 \%$ と最も多 かった。その他特徵的なものとして精神障害が $4.5 \%$ に 認められた。 また, 術前の心電図では何らかの異常を 認めたものが $68.2 \%$ \%のぼっていた（Table 6).

5）高齢者群の術後合併症と危険因子

80 歳以上高齢者群の手術例における術後合併症の発 生率は $28.8 \%$ (19例/66例) で, その主なるのは縫合不 全 $9.1 \%$, 肺炎 $6.1 \%$, 腸閉塞 $4.5 \%$ であり, 術後一過性 の精神障害が7.6\%にみられたこのうち予後に直接影 
Table 6 Preoperative complications of patients with gastric cancer over 80 years of age

$\begin{array}{lrl}\text { Hypertension } & 16 & (24.28) \\ \text { Pulmonary disease } & 10 & (15.28) \\ \text { Urogenital disease } & 7 & (10.68) \\ \text { Diabetes mellitus } & 3 & (4.58) \\ \text { Heart disease } & 3 & (4.58) \\ \text { Senile dementia } & 3 & (4.58) \\ \text { Cholelithiasis } & 2 & (3.08) \\ \text { Others } & 4 & (6.18)\end{array}$

Table 7 Postoperative complications of patients with gastric cancer over 80 years of age

\begin{tabular}{lll}
\hline Leakage & 6 & $(9.18)$ \\
Dementia & 5 & $(7.68)$ \\
Pneumonia & 4 & $(6.18)$ \\
Ileus & 3 & $(4.58)$ \\
Bleeding & 2 & $(3.08)$ \\
Others & 2 & $(3.08)$ \\
\hline
\end{tabular}

Table 8 Comparison of preoperative laboratory findings of patients with gastric cancer over 80 years of age between complicated group and non-complicated group

\begin{tabular}{|c|c|c|c|}
\hline \multirow[b]{2}{*}{ item } & \multicolumn{2}{|c|}{$\mathbf{m} \pm \mathbf{S D}$} & \multirow{2}{*}{$\begin{array}{l}\text { mean } \\
(\mathrm{n}=66 \mathrm{6}\end{array}$} \\
\hline & complicated group & non-complicated group & \\
\hline$(8)$ & $74.7 \pm 16.7$ & ${ }^{*} 95.3 \pm 16.8$ & 92.2 \\
\hline \% FEV $1.0(8)$ & $73.4 \pm 6.1$ & $77.8 \pm 8.4$ & 77.1 \\
\hline Albumin & $3.5 \pm 0.3$ & $3.6 \pm 0.5$ & 3.6 \\
\hline$\left(/ \mathrm{mm}^{3}\right)$ & $6400 \pm 1124$ & $5902 \pm 1820$ & 5980 \\
\hline Lymph.C. $\quad\left(/ \mathrm{mm}^{3}\right)$ & $1101 \pm 485$ & $1486 \pm 603$ & 1425 \\
\hline Hemoglobin $(g / d l)$ & $11.1 \pm 1.5$ & $11.4 \pm 1.9$ & 11.4 \\
\hline$(\mathrm{mg} / \mathrm{d} 1)$ & $118 \pm$ & $113 \pm$ & 114 \\
\hline ( K.U) & $22 \pm 9.1$ & $22 \pm 7.5$ & 22.0 \\
\hline ( K.U) & $11.9 \pm 6.2$ & $12.3 \pm 4.9$ & 12.2 \\
\hline$(\mathrm{mg} / \mathrm{dl})$ & $18.7 \pm 8.1$ & $18.1 \pm 6.2$ & 18.1 \\
\hline $\mathrm{NSRI}^{\mathrm{k}}$ & $41.3 \pm 3.8$ & $43.6 \pm 6.1$ & 43.2 \\
\hline
\end{tabular}

$(* P<0.05)$

( $\star$ * NSRI : Nutritional Surgical Risk Index $=10$ Alb.+ 0.05Lymph.C )

Fig. 3 Distribution of preoperative value of \%VC between complicated group and non-complicated group in patients with gastric cancer over 80 years of age

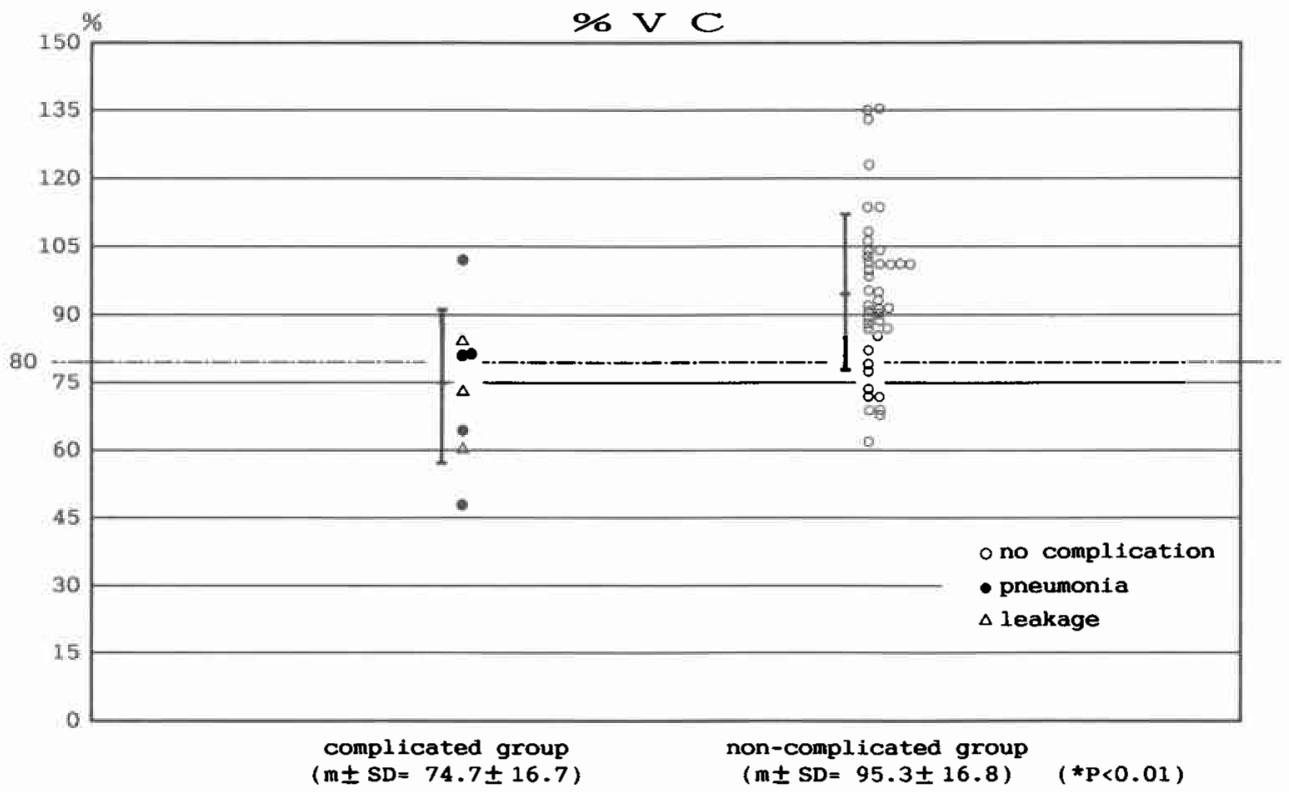


響を及济すと考えられる縫合不全と肺炎の合併症に限 り，これら術後合併症の発生に関する危険因子につき 検討を加点た (Table 7).

80 歳以上の高齢者群を, 艂合不全をたは肺炎の発生 をみた合併症群と，合併症のなかった非合併症群に分 け, 両者間で術前の各検查項目につき比較検討した結 果, 術前の肺活量\%VC に有意差を認めた $(\mathrm{p}<0.01)$ (Table 8).すすなわ，術前の肺活量\%VCの平均値は 合併症群では $74.7 \%$ で, 8 例中 4 例が $80 \%$ 未満であっ たのに対し, 非合併症群の平均値は $95.3 \%$ あった (Fig. 3). また, 術式およびリンパ節郭清度別にみた術 後合併症の発生率に差は認められず, 非切除例でも 9 例中 2 例に縫合不全と術前から併存疾患としてあった 痴呆の増悪を認めた。

\section{考 察}

急速な高齢化社会の到来に伴い高齢者胃癌症例は増 えつつあり，また麻醉管理および術前・術後の管理の 進歩により，われわれ外科医にとって手術の対象とな る症例も多くなり, 特に近年その感は強い. 高秢者の 概念も時代とともに变化しているが，先に述べた理由 から今回われわれは75歳以上を高齢者とし, 高龄者胃 癌の持つ外科治療上の問題点をより明らかにするため に80歳以上の高龄者胃癌を 74 歳以下の胃癌症例と比較 検討した。

性別は80歳以上では, 男女比 $3.1: 1 て ゙ 74$ 歳以下は 1.7：1と高齢者群でより男性に多い傾向がみられた。 高齢者胃癌の占居部位は A 領域が多く, 肉眼分類では 早期癌は I 型, IIa 型の隆起型が, 組織学的には高分化 型が多かったことはほぼ諸家 ${ }^{213)}$ の報告と同様であっ たが, 進行癌では Borrmann 1 型と 2 型が多くなる傾 向はみられたものの有意差は認められなかった。

多発癌は 80 歳以上で $12.3 \%$ ( 7 例) に認められ，74 歳以下の $5.3 \%$ にくらべ有意に高く $(\mathbf{p}<0.05)$, この点 は術前検査および切除範囲を決める際の注意点と思わ れた4)。

手術内容についてみると, 高齢者胃癌は肝転移やリ ンパ節転移が高率で全身状態不良のため切除率が低い とされる報告もあるが3)，今回われわれの検討では, 80 歳以上高齢者胃癌の切除率执よび胃全摘率は74歳以下 と全く変わらずむしろ高い傾向にあり, 積極的に切除 がなされて来た結果である. しかし，切除直死率は74 歳以下の $0.8 \%$ に比べ $5.3 \%$ と有意に高く，この点に高 齢者胃癌の抱觉る1つの大きな問題がある。

80 歳以上と 74 歳以下の両者間活括ける進行程度に差
は認められなかった。リンパ節転移に関しては, 74歳 以下の $\mathrm{n}(+) 50.3 \%$ に比へ， 80 歳以上 $\mathrm{n}(+) 61.4 \%$ と, 高齢者群ではリンパ節転移陽性率が高くなる傾向 があり, 紀藤ら4の報告と同様であった。しかし，一方 では児玉ら 5 の様に80歳以上の胃癌は深達度, リンパ 節転移傾向の緩和な進行度の軽い症例が多いとするも

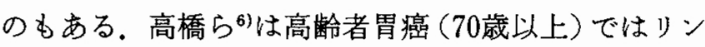
パ節転移が 2 群までに止末る率が高い傾向にあると報 告しており，今回われわれの成績です 80 歳以上では, $\mathrm{n}_{1}(+)$ または $\mathrm{n}_{2}(+)$ が $56.1 \%$ と 74 歳以下の $42.4 \%$ に比べて高いものの, $\mathrm{n}_{3}(+)$ 以上は $5.3 \%(74$ 歳以下 $7.9 \%)$ と低くなる傾向にあった。しかしこれには高龄 者群の手術に抢けるリンパ節郭清度の低下が影響して いるものと思われるので断定はできない.

高齢者胃癌に対して切除を行ら際, リンパ節郭清を との程度をで行らかは手術侵襲との関係から, 外科医

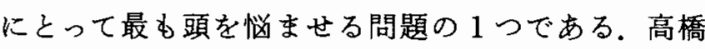
ら゙)は，高齢者ではリンパ節転移が 2 群までに止まる 率が高い傾向にあるので, 治瘛切除が可能と判断され た場合は $\mathrm{R}_{2}$ までの郭清を行うことが望ましいとし, 平

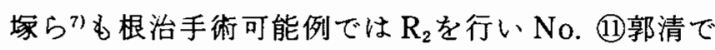
は膵を温存するのが望ましいと述べている。一方，中 野らダは術侵襲を少なくすることも目的の1つである が, 高齢者では組織学的に分化型が多いことから，必 要最小限度の胃切除々転移陽性と考えられるリンパ節 の郭清にとどめることを原則としていると述べ，押淵 ら9は高龄者に対するリンパ節郭清の範囲は単に大き ければ良いというものではなく, 郭清範囲の縮小によ り手術侵襲を軽減することが必要としている。さらに 榊原ら ${ }^{10)}$ は胃癌取扱い規約にいう R-numberにこだわ らず，重点的なリンパ節郭清を行う力がよりよいとし ている、われわれの検討では，高路者胃癌はリンパ節 転移陽性率が高くなる傾向はあるるのの組織学的に分 化型が多い結果が得られているので，全身状態が許せ ば治癒切除をめざすが，不良の場合は転移陽性と考兄 られるリンパ節の重点郭清による合理的な手術が望を しいと考えている.

治窟切除と遠隔成績との関係では，平均余命の少な い高龄者では他病死例が多くみられたが，他病死例を 除いた 5 年生存率は66.2\% と, 74 歳以下の $74.8 \%$ と比 べほぼ满足できる結果であると思われた。

高齢者胃癌の外科治療上の最大の問題点はいかに術 後合併症の発生を少なくするかであり，そのためには まず的確かつ総合的に術前状態を判断する必要があ 
る. 当科において70 75歳と 75～79歳の年龄層の胃癌 症例は, 全く同等な手術の安全性と術後成績が得られ ており75 79歳の胃癌に対しても積極的な態度で手術 に臨むべきであると佐々木は報告したが，80歳以上の 高齢者に打いては切除直死率, 術後合併症の発生率は 高くなっている ${ }^{11}$. その理由としては, 高齢になる活ど 加齢之老化による生体防衛反応の低下 ${ }^{12}$, 種々の臟器 の予備力の低下 ${ }^{13) 14}$ )がより顕著となるためであり，こ れらの状態に縫合不全, 重症感染症が起これば比較的 容易に多臟器不全へ移行する危険性を含んでいる。 そ こで80歳以上の高齢者胃癌症例の手術の安全性と限界 を考えるために術前併存疾患および術前検査成績と術 後合併症との関係を検討し, 術後合併症の発生に関す る危険因子の把握を試みた。

高齢者胃癌の術前併存疾患についてみると，全体の 有病率は $65.2 \%$ に達し, 高血压症が $24.2 \%$ と最も多く, 次いで結核や肺炎などの呼吸器疾患・泌尿器疾患・糖 尿病の順であった。 また，術前より精神障害がみられ た症例が $4.5 \%$ に存在したことは高齢者の特徵と思わ れた。術前の心電図にはブロック・心筋虚血・左室肥 大・期外収縮など何らかの異常を認めたものが $68.2 \%$ にのぼっていた。 しかし, 循環器系, 呼吸器系に手術 適応外となるような重篤な既往はほとんどみられず， 暦年齢に比べて生活年龄が若い印象を受ける症例る少 なくなくこの点 80 歳以上高柃者はエリート集団であ るという山城15)の表現は適切と思われた。

高齢者群に扔いてリンパ節郭清度別に術後合併症の 発生率をみると, $\mathrm{R}_{0} 33.3 \%, \mathrm{R}_{1} 26.3 \%, \mathrm{R}_{2} 28.0 \%\left(\mathrm{R}_{3}\right.$ は 1 例のみで術後合併症なし) と, 相関はみられなかっ た. $\mathrm{R}_{0}$ でも合併症の発生率が高かったのは, 高度進行 例が多く担癌による潜在的な全身状態の低下が原因と 思われた。したがって高齢者胃癌では，非治癒切除お よび非切除例に対する手術適応は慎重に決める必要が あると思われ，われわれの直死例の 1 例も絶対的非治 癒切除例であった。この点に関して合併症発生率や直 死率は非治癒切除例と非切除例で高く，遠隔成績も極 めて不良なため切除不能と判断される症例では手術適 応を慎重に決め, 最小の手術侵襲にとどめるべきとす る点で諸家の意見の一致がみられている ${ }^{16) 17)}$. なた, 高 路者群での胃全摘例16例のうち開胸例は経験していな いが, 他缄器合併切除例は 4 例で, 脾合併切除 1 例, 膵脾合併切除 3 例であった。このうち直死例は 1 例 む 認めていないが, 術後合併症の発生率は $31.3 \%$, 痴 呆 2 例, 肺炎 1 例, 腸閉塞 1 例, 術後出血 1 例であっ
た。

術後合併症発生率と手術時間には相関は認められな かったが, 術中出血量の増加に伴い術後合併症の発生 率は高くなる傾向がみられた。したがって, 術後合併 症群では術後の総輸血量も有意に多くなっており $(\mathbf{p}<0.05)$, 術後合併症の予防には術中出血量の軽減 が重要であると思われた。

高齢者胃癌の術後合併症で最も重要なものは縫合不 全と肺合併症であり, われわれの経験した直死例 3 例 はいずれも縫合不全から肺炎を併発し呼吸不全に至っ たものである。この術後合併症の発生に関する危険因 子の検討では, 術前の肺活量\%VCが1つの指標にな るものと思われた。術前呼吸機能異常のある場合はも ちろんのこと, 検査成績上は異常の見られない症例で も80歳以上の高龄者では諸藏器予備能が低下している 事を考慮し，術前より IDSEP (increased dead space and expiratory pressure) P IPPB (inter mittent positive pressure breathing) の呼吸訓練を十分に施行 することが望ましい. 縫合不全の予防に対しては NSRI (nutritional surgical risk index) ${ }^{18)}$ の低下した 症例がほとんどであることにより, 術前の栄着状態や 筫血を十分に改善することが肝要である。 また，術後 合併症発生群では入院時 $37.0^{\circ} \mathrm{C}$ 以上の発熱を認める症 例が多く,さらに術前の末梢血液中のリンパ球数の減 少傾向が認められた. 高度進行症例での術前の発熱は しばしば経験するところであるが，これがどの様な意 味を持つのかは, 他の免疫学的検查と合わせ今後検討 をさらに加えて行きたいと考劣ている.

その核か, 高齢者胃癌の特徵として, 生命に直接の 危険を及ぽするのではないが, 術後の一過性の精神障 害むみられ，この点に関して林ら ${ }^{19}$ は物心両面あらゆ る点にわたるきめ細かい配慮の必要性を述べている。

最近注目されている内視鏡治療では, 梨本ら ${ }^{201}$ は適 応を, 高秢者で長径 $1 \mathrm{~cm}$ 以下の隆起性 $\mathrm{m}$ 癌としてお り, 術後合併症の問題や quality of life の面から, 今 後適応症例が増加するものと思われる。

平均余命の少ない高龄者における治療の基本は，い かに直死率を下げ合併症の発生を抑光るかにかかって いるといえる. 手術適応, 術式の選択については年齢 や免疫能括よび諸臟器予備能の低下といった生体側の 要因以外にも, 術後合併症の発生率が高く予後に执い て他病死が多い特性や社会的適応を考慮にいれ，家族 の受け入れ体制に関する informed consent を十分に 行い,さらに quality of lifeを重視し総合的に判断す 
る必要があると考觉る。

な拈本論文の要旨は, 第35回日本消化器外科学会総会(伊 勢市）1990年 2 月において発表した.

\section{文献}

1）胃癌研究会：胃癌取扱い規約. 第11版, 金原出版, 東京, 1985

2）吉井由利, 小林世美, 春日井達造活か: 高齢者胃癌 の臨床. 癌の臨 $19: 847-851,1973$

3）寺部啓介, 亀井秀雄, 赤塚 聰注か：高柃者胃癌の 臨床免疫学的特徵。外科 $41: 675-680,1979$

4）紀藤 毅, 山田栄吉, 宮石成一经：高路者胃癌の 外科治療に拈ける問題点. 日外会誌 83 : 1077-1080, 1982

5）児玉好史, 倉重誠二, 岡村 健渒か：高柃者胃癌の 病理学的特徵々外科的治療方針. 日外会誌 83 ： $1081-1084,1982$

6) 高橋宣胖, 平井勝也, 久富 沖活か：手術直接死亡 例からみた高龄者胃癌治療の問題点。日外会誌 $83: 1094-1098,1982$

7) 平塚正弘, 古河 洋, 岩永 㓮攺か：80歳以上高龄 者の手術一胃の手術。臨外 $44: 213-217,1989$

8）中野眼一, 中村卓次, 坂本孝作任か：高齢者胃癌の 術後成績々合併症対策。日外会誌 83 : 1099-1103, 1982

9）押淵英晃, 大津哲雄, 野田剛稔涂か：癌占居部位々 切除範囲加らみた高踰者胃癌治療の問題点. 日外 会誌 $83 ： 1085-1089,1982$
10）楖原 宣, 梶原哲郎, 小川健治：高齡者胃癌の手 術。外科 $44: 1383-1386,1982$

11）佐々木壽英, 赤井貞彦, 島田寛治法加：高歯者胃癌 の現状と問題点. 癌の臨 $29: 880-886,1983$

12）岸本 進：加齢々免度異常. 代識 $12: 771-779$, 1975

13) Kohn RR: Human aging and disease. J Chron Dis $16: 5-21,1963$

14) Evans TI: The physiological basis of geriatric general anesthesia. Anaesth Intens Care 1 : 319-328, 1973

15）山域守也：老年者の手術一複合障害がある場合. 臨外 33:1123-1134，1978

16）中島 聰, 太田恵一郎, 西 満正: 高龄者胃癌症例 に対する手術很襲とリスクファクターの解析。日 消外会誌 $19 ： 2104-2107,1986$

17）羽生 丕, 鴻野雅司, 谷 雅夫ほか：高齢者胃癌の 適応判断。日消外会誌 $20 ： 2427-2430,1987$

18）小野寺晴夫：術前・術中・術後の管理. 外科 Mook $37: 54-63,1984$

19）林四郎，志賀知之：興味ある術中術後の合併症 とその対策一術後早期に出現する一過性の精神障 害. 外科䛦療 $23: 1694-1698,1981$

20）梨本 篤, 佐々木壽英, 赤井貞彦ほか：外科医の立 場からみた早期胃癌に対する根治的内視鏡治療の 可能性. 外科骖療 $30: 1224-1231,1988$

\title{
Evaluation of Surgical Treatment for Aged Patients with Gastric Cancer (Over 80 Years of Age)
}

\author{
Kouichi Higashiyama, Atsushi Nashimoto, Juei Sasaki, Sadahiko Akai, Kiyoshi Kato, \\ Muneaki Sano and Mitsuhiro Tsutsui \\ Department of Surgery, Niigata Cancer Center Hospital
}

To identify the problem of surgical treatment for the aged patients with gastric cancer, the clinico-pathological findings in 66 patients over 80 years of age (Group A) were compared with those in 4066 patients under 74 years of age (Group B). The conclusions were as follows: 1) There was no difference in resectability and rate of total gastrectomy. The operative mortality was $5.3 \%$ in group A and it was significantly higher than that in group B $(p<0.05)$. The frequency of postoperative complications was high $(22.8 \%)$ in group A. 2) Charactaristics of carcinoma in group A was clear differentiation of histology and tendency of high grade advancement in lymph node metastasis. 3) Except for other cause of death, the five-year survival rate with curative resection was satisfactory in group A $(66.2 \%)$. 4) A lowering preoperative \%vc should be considered a risk factor for postoperative complications in group $A$. These results suggest that radical resection should be performed in aged patients over 80 years old if their general condition allows it. If not, rational surgical procedures are desirable.

Reprint requests: Kouiti Higashiyama The Division of Surgery, Niigata Cancer Center Hospital 2-15-3 Kawagishicho, Niigata City, 951 JAPAN 